\title{
Nation-State-University: Which Flag must a University Unfurl?
}

\author{
Satarupa Chakraborty*
}

\section{Abstract}

There is a long history to the debate of nationalism. The Indian nationalism has emerged after a long people's movement - the truth to which is often denied by a range of forces who have specific sectarian ideological leanings. This paper is an attempt to revisit the historical context in which Indian nationalism has emerged and evaluate it in reference to the contemporary time. It emphasises on the relation between the nation and the state with special reference to its impact on the universities. Further, the paper suggests that in order to uphold the idea of university and nation, an inclusive and secular idea of nation has to be espoused. Lastly, it suggests that a university needs to foster a non sectarian approach and broaden its vision for an internationalist outlook.

Keywords: Nationalism, University, Anti-colonial struggle, Secularism, Critical thinking

\section{Introduction}

Rock-paper-scissor. The rule of the game- paper hides the rock, scissor cuts the paper, and rock breaks the scissor. Who does win? An analogy in contemporary- and perhaps, historical world of contradictions barring profound cynicism could play- nation-stateuniversity. Nation discomforts state, state wraps a university, a university questions the nation! Who does win? Perhaps, a univer-

\footnotetext{
* Center for Philosophy, School of Social Sciences, JNU, New Delhi, India; satarupa.jnu@gmail.com
} 
sity. A university questions everything. In this process, a university could discomfort everyone, indeed, in purpose. When a university questions, this analogy falls apart. There ceases to exist the stable strategies.

The tenets of nationalism though largely seek refuge in the geographic boundaries of cultural identities, the emergence, formation and normalisation of nationalism itself is far more complex than the mostly singular narrative that it adheres or usurps at certain point in time. The multitude of narratives around nationalism, even in the Indian subcontinent, points to the inherent diversity in its conceptualisations based on the political history over time (Habib, 2017). Nationalism is, thus, not inherent and derived from the abstractions of the concept(s) of nation itself. It is, rather, established that the modern ideas of nations are often demarcated and linked to the boundaries of the political states, constructing the further imaginations of the nations to the even more truncated nationstates. The ideas of nationalism that shaped the modern nationstates in the global south emerged through the anti-colonial struggle (Habib, 2017). Thus, in the human history, both nation and nationalism are, indeed, recent political conceptualisations, which do not even predate a couple of centuries (Motyl, 2000).

This, as well, is true for the Indian subcontinent. The Indian nationalism emerged through the anti-colonial struggle against the British imperialism (Habib, 2017). It amalgamated a wider set of ideas, drawn at the various points in time of the struggle itself. Thus, the idea of Indian nationalism in the 1750s differed from that of the 1850s and 1950s. Since the early 1900s, increasingly the political leadership, writers, thinkers of the subcontinent, including Mahatma Gandhi, BR Ambedkar, Rabindranath Tagore and several others had to grapple with the ideas of nationalism. This was also a period when the anti-colonial struggles had spread and taken roots across the subcontinent in a larger democratic movement. In comparison with early 1800s, for instance, the early 1900s witnessed the spread of the anti-colonial struggles among a more diverse section of people and areas. A political unity was required to intensify the anti-colonial struggle, which the ideas of nationalism seized. Much later, political leader and thinker like Jayaprakash Narayan in "Origin of Nation" acknowledged this: "...while it is not possible to 
state definitely when nationality as we know today was born, it would not be wrong to say that the second half of the 18th century saw its first beginnings. The 19th was par excellence the century of nationalism." (Habib, 2017, p. 257).

The question of nationalism in India is, therefore, a formation that embraced the unity in democratic response to the political order of the colonial rule, while recognising throughout the diverse views that shaped its imaginations.

However, in the recent years in different spheres of public life in India, nationalism - and more particularly, certain specific ideas of nationalism is increasingly seeking conformity. This has transcended beyond the political rhetoric to an effort to shape several institutions. The disquiet made public headlines and international attention when nationalism demanded allegiance in the universities and institutions for higher learnings in India. This rather restricted and enforced idea of nationalism, definitely not only limited to India, is argued to be antithetical to knowledge and fundamentally stand opposed to the idea of a university.

In the backdrop of such an understanding, the idea of nation and nationalism were the political boundaries of the state delimited. The legislative formulations of universities are within the bounds of the state in modern times. In the context of Indian subcontinent (and much of the global South), the idea of a nation could not be subsumed in the limits of a state. Similarly, the idea of a university could not be thought as an extension of the state to carry forward state's political prerogative or an exhibition of state's notion of the nation.

This article focuses on identifying the concepts and ideas of the nation, nationalism and a university with specific attention to the contemporary dominant discourse in India. There are numerous studies bringing forth the historical role of universities and this article is not an attempt to draw the historical pedagogic role that a university must play. Rather, while discussing and drawing references to the chronology of the concepts of the nation, nationalism and a university, the article would particularly focus on the idea of nationalism propounded by the ideology, that of Hindutva, a contempo- 
rary dominant political force-vis-à-vis education in general and more specifically to the public universities.

\section{Nationalism and its dominant contemporary overtures}

At the formative stages of Indian nationalism during the anticolonial freedom struggle, the many views were espoused (Habib, 2017). It is also important here to point the obvious- that the Indian at that point embraced a synthesis of nationalism that include and, rather, being participated upon by the individuals and communities from the territory of the subcontinent under the then British rule. Therefore, it was broader, diverse, inclusive and nonsectarian. Historian Romila Thapar points this out: "We understood nationalism to be Indian nationalism and not Hindu or Muslim or any other kind of religious or other nationalism, and a clear distinction was made between nationalism and other loyalties."(Thapar, 2016, p. 3)

Though subnational identities tried to appropriate as representative of a larger nationalism, particularly at the first half of 1900s, the idea of nationalism derived from pluralism and heterogeneity could galvanise the popular imagination. The modern nation-state of India, with its constitutional promise and vision, is representative of multitude of views.

Since the nature of Indian nationalism has a diverse historical root, identifying the same with any particular religion or cultural identity, forms the basis of a sectarian, communal or chauvinistic distortion to the nationalism project itself.

An important case that has both historical and contemporary relevance is the ideas of nation and nationalism of a specific ideology. MS Golwalkar, an influential leader who resonated the same ideology identified five components- "country, race, religion, culture and Language" as elements which are irrefutable to be constituent of the 'national'. He wrote:

....the modern understanding of 'Nation' to our present conditions, the conclusion is unquestionably forced upon us that in this country, Hindusthan, the Hindu Race with its Hindu Religion, Hindu Culture 
and Hindu Language, (the natural family of Sanskrit and her off-springs) complete the Nation concept; that, in fine, in Hindusthan exists and must needs exist the ancient Hindu nation and nought else but the Hindu Nation. All those not belonging to the national i.e. Hindu Race, Religion, Culture and Language, naturally fall out of the pale of real 'National' life. (Golwalkar, 1939, pp. 43-44)

Golwalkar advocated for achieving freedom through 'defending religion and culture' rather than fighting against the British colonialism. Shamsul Islam in his critique to Golwalkar's definition of nation raises rigorous criticism against the approach of SavarkarGolwalkar model to define India as a nation with one race-religionculture-language and refuses to term India as a 'Hindu nation' (Islam, 2017). Similarly, Romila Thapar argues: “...concepts of nations based on a single exclusive identity - religious, linguistic, ethnic and similar single identities - are actually pseudo-nationalisms and should be precluded from being called a nationalism, without the accompanying qualifier of their identity" (Thapar, 2016, pp. 7-8). Therefore, defining nationalism in the light of a particular religion, culture and language goes against the very idea of nationalism with which the wide and diverse section of people in the subcontinent associated with and thereby, shaped it. It is in this context, as the historians argued, we must have an inclusive idea of nationalism which inherits its root in the people's movement against the colonial rule. Keeping this vision of nationalism in mind, it is important to look at the concept of nation-state relation in contemporary time vis-a-vis modern Indian institutions of higher education and learning.

\section{Subsuming the nation under the state}

The nation has broad meanings. As we have seen, it is not limited to any particular identity or culture. The state, on the other hand, is not to be compared with the nation as the nation provides a certain universal standards for the state to perform those in order to guarantee the rights of the people as laid down in the nation's constitution (Guru, 2016). Gopal Guru argues in a public teach-in lecture on nationalism at the Jawaharlal Nehru University: 
The state should not become more important than the nation. The state, particularly its existence, i.e., government, has to take precautions so that it does not subordinate the nation to its narrow interest...

......The State, rather than the common people, is defining the meaning of nation and soliciting people's support to this particular meaning of nation by disciplining them through splashing sedition charges against them. It is important, therefore, to free the nation from the unreasonable and hence undesirable grip of the state. (Guru, 2016, p. 10)

Thus, it is a dangerous proposition to subsume the idea of a nation to the apparatus of a state. It is dangerous not only because it runs the risk of contriving the trajectory of formation of a nation to a singular ally of political and ideological dispensation that centrally assumes the state power, but also- and rather, more importantly, it rejects the history itself.

If the state could usurp itself as nation, it is, rather, convenient for the rulers to disallow even the discussion and engagement with a diverse view of nationalism, which is not in consonance with one particular ideological-political position or programme.

\section{Summoning universities to court nationalism}

If a single narrative must be adhered to, then classrooms, universities and institutions for higher learnings are definitely the most unsuitable of spaces. Yet, when a mob settles at the gate of an university perturbed by the diverse tradition of debate; when proposals emerge to install battle tanks to instill nationalism in universities; when length of the national flag become an important consideration and the Human Resource Department dwell in setting the height of the mast higher - the idea of universities itself receive a fatal blow.

When a qualifier for a nationalism test has been set for the universities and institutions, it is expected that the ideas of nationalism and nation would be severely discussed (Azad et al., 2016). However, at every instances of such discussions and debates, the state's narra- 
tive of 'one nation' was exposed in relation to the historicity of nationalism in India. This has brought tremendous wrath to the point that there was, for instance, a campaign for shutting down of one of the country's best universities (\#ShutDownJNU campaign). But this is far from being restricted to one particular educational institution.

In later half of 2016, a stage adaptation of Mahasweta Devi's critically acclaimed short story Draupadi $i$ by the Department of English and Foreign Languages at the Central University of Haryana in the memory of the author who passed away that year, was met with slanders, hooliganism and finally an administrative clampdown. The story and the play, allegedly, were not in sync with the 'onenation'-nationalism-narrative that made the complaints harass and intimidate the teachers and students. These instances are not new, though, and recurrently emerged-sometime throttling the universities, sometime the teachers, sometime the students. In every instance, however, it is to enforce a singular narrative of the nation and its subsequent corollaries. This is also an important pointer that the scale at which the higher education institutes are been targeted for their pedagogic engagement is unprecedented. The campuses are restive in response and is clearly in public discussion. Film and Television Institute of India (Pune), Indian Institute of Technology - Madras, University of Hyderabad, Jadavpur University (Kolkata), Allahabad University, Banaras Hindu University, Aligarh Muslim University, Jodhpur University, University of Delhi, Pondicherry University, Gauhati University (Guwahati) - the list of campuses are long, spread across the country and are known historically as important centres of learning.

The binary of 'national' and 'anti-national' to, further, profile individuals for their views is a threat to both the freedom of expression and the spirit of the constitution. This stream of nationalism is antithetical to the idea of a university as it defines its meaning in terms of a certain homogeneous identities rather than standing with the principle of plurality, inclusivity and freedom. SavarkarGolwalkar's view of nation and nationalism is one among the many and largely divorced from the anti-colonial struggle which shaped the Indian nationhood (Thapar et al., 2016). 


\section{Conclusion}

In contemporary India, it is undeniable that the universities, research institutions and public institutions for learning are at a phase, where intellectual assertion and its social role of critical thinking must be non-negotiable. The last few years have seen scathing attacks on writers, journalists, researchers and academicians for upholding their ideologies, being critical of singular narratives and resisting a curbing of democratising of the university spaces. The reasons for the non-negotiations are not inherent to the idea of the university itself, rather to uphold its independence from the clutches of societal beliefs or state's notions alike.

There are many ideas of nationalism. Nationalism in Indian subcontinent, as discussed in detail, was shaped through the anticolonial struggle. However, not all sections historically participated in the anti-colonial struggles. For some of them, the emphasis on identities (viz. religion, caste, language) remained central. If a sense of nationalism is drawn for such contrived identities, they remain exclusionary. Savarkar-Golwalkar, for instance, clearly set their views of nation on the lines of the certain identities, narrowing even a culturally and philosophically diverse Hindu religion to a contrived form of cultural practice restricted to sections of the upper caste. This, if assumes as the central pole of Indian nationalism would stand historically inaccurate and insufficient in shaping the idea of nation in the subcontinent.

It reinforces the need to stimulate a debate, both in academic spaces and among people, on the idea of nation, nationalism and universities. Universities have a critical social function. It predates nation as an idea. Universities of Bologna (1088 CE), University of Oxford (1096 CE), University of Cambridge (1209 CE), University of Padua (1222 CE) are among some of the several others which are still operating since their inceptions prior to the formation of the nations. In the subcontinent, the earliest universities like University of Calcutta, University of Madras and University of Bombay, all set by the colonial rulers in 1857, primarily for teaching, played a long standing social role and still remain as important centres of learning in the country. The Banaras Hindu University (1916), started with the initiative and vision of educator and political activist Ma- 
dan Mohan Malviya embraced the nationalism that was shaped through anti-colonial struggles and hence the necessity to build nations.

None of these universities exist today because they adhered to a particular idea of nation or nationalism. That was not the prerequisite. Rather, the internationalist outlook of a university could, perhaps, have shaped their trajectories and future.

\section{References}

Golwalkar, M. S. (1939). We or our nationhood defined. Nagpur: Bharat Publication.

Guru, G. (2016). Taking Indian nationalism seriously. In R. Azad, J. Nair, M. Singh, \& M. S. Roy (Eds.), What the nation really needs to know: The JNU nationalism lecture (pp. ix- 339). New Delhi: Harper Collins Publishers India.

Habib, S. I. (Ed.). Indian nationalism: The essential writings (3 ${ }^{\text {rd }}$ ed., pp. 1285). New Delhi: Aleph Book Company.

Islam, S. (2017). Golwalkar's we or our nationhood define: A critique (pp. 7216). New Delhi: Pharos Media \& Publishing Pvt Ltd.

Motyl, A. J. (2000). Encyclopedia of nationalism, Two-Volume Set. Elsevier.

Thapar, R. (2016). Reflections on nationalism and history. In Thapar R, Noorani A. G., Menon S, On Nationalism (1 ${ }^{\text {st }}$ ed., pp. 1-162). New Delhi: Aleph Book Company.

$i$ Apoorvanand, a professor at Hindi Department of the University of Delhi highlighted the importance to re-think about these critical points in a short article after the clampdown and setting of High Level Enquiry Committee at the Central University of Haryana over the staging of Mahasweta Devi's 'Draupadi'. The professors, who were involved in the staging of the play, were at the receiving end of a slanderous campaign, media trial and the enquiry committee. https://scroll.in/ article/ 818247 /draupadi-and-the-haryana-university-fracas-theres-a-hero-inthis-story-and-it-is-not-the-abvp 